\title{
The Analysis of Conditions of Hydraulic Backhoes Use in the Coal-Bearing Zones at Kuzbass Open Pits
}

\author{
Andrew Strelnikov ${ }^{1, *}$, Michal Radek ${ }^{2}$, Markus Stolz ${ }^{3}$, and Ralf Rosenberg ${ }^{3}$ \\ ${ }^{1}$ CJSC Stroyservice, 650055 Kemerovo, 121 Kuznetsky Avenue, Russian Federation \\ ${ }^{2}$ University of Miskolc, H-3515 Egyetemváros, Miskolc, Hungary \\ ${ }^{3}$ Vienna University of Technology,1040 Karlsplatz 13, Vienna, Austria
}

\begin{abstract}
The period of open pit mining development in Kuzbass (Western Siberia, Russia) until the mid-1990s was characterized by the application of rope and hydraulic shovels in coal-bearing zones, the work of which is not effective enough due to a decrease in productivity in mining operations, high losses and dilution of coal. The supply of this type of excavators was fully provided by Russian excavators' manufacturers. With the transition to market relations since the early 90 's, in the coal industry of the Kuzbass two interrelated phenomena have occurred. First, the restructuring of coal industry and the massive privatization of licensed development of explored deposits forced a sharp increase in the open pit construction (from 24 in the early 1990's to 62 now). Secondly, the bankruptcy of excavators' manufacturers led to a reduction in the volume of production of domestic rope shovels. So the problem of defining the conditions of hydraulic backhoes use in the coal-bearing zones became very important.
\end{abstract}

\section{Introduction}

Since the world market of mining and transport equipment for quarrying was opened for Russian coal producers, which offers both powerful rope shovels and a wide range of hydraulic shovels and backhoes. The latter, widely used at open pit mining in world-wide coal industry, have began to be actively introduced on Russian coal open pit mines. Light, manoeuvrable, inexpensive, but short-lived, hydraulic backhoes have began to fill a special sector of quarrying - coal-bearing zones of quarry fields, displacing rope backhoes from them.

However, hydraulic backhoes introduced for complex-structured coal-bearing zones development on the Kuzbass open pits, are used for stratum of seams extraction (from 2-3 to $12-14$ seams), with different dip angles - from $4-5^{\circ}$ to $90^{\circ}$, and various thickness of rock interbeds (from 3-4 $\mathrm{m}$ to $80-120 \mathrm{~m}$ ) [1-3]. It pointed a set of scientific and practical tasks for the adaptation of hydraulic excavators to the mining and geological conditions of

*Corresponding author: a.strelnikov@stroyservice.com 
Kuzbass in order to effectively use the working parameters and ensure high productivity of hydraulic backhoes.

The need to adapt hydraulic backhoes to the conditions of coal-saturated zones is due to the presence of contradictions between the technological conditions of mining operations in these zones and the conditions for the effective use of hydraulic excavators (backhoes).

\section{Materials and Methods}

Technological features of open pit mining operations in the coal-bearing zone are:

- the height of the bench here is equal to the height of the bench of the coal-less zone, where powerful rope shovels made in Russia and former Soviet Union (ECG-5A, ECG-8I, ECG 10, ECG-12, ECG-15, ECG-20 with bucket capacity 5-20 $\mathrm{m}^{3}$ ) and "Harnischfeger" models are used, with the bench height of 10-16 m. The equality of the heights of the benches in both zones is due to technological requirements [4-6];

- in the calendar planning, trenches and coal-and rock stopes are cut with the height equal to the height of benches in the coal-less zone. When they are developed, an alternate excavation of rock and coal is carried out.

Scientific researches and practice have established that the highest productivity of hydraulic backhoes is achieved with downward digging at a height of 4-5 m, which requires layered trenching and development of stopes.

Table 1 shows the values of the height of the layers $(h l)$ according to the theoretical studies and practice adopted in this paper.

Table 1. The excavated layer's height for mining coal-bearing zones by hydraulic backhoes.

\begin{tabular}{|c|c|c|c|c|}
\hline \multicolumn{3}{|c|}{ Theoretical clauses [1] } & $\begin{array}{c}\text { The layer's height } \\
\text { at Kuzbass open } \\
\text { pits }\end{array}$ & $\begin{array}{c}\text { The number and } \\
\text { height of the layers } \\
\text { adopted in this } \\
\text { paper }\end{array}$ \\
\hline \multicolumn{3}{|c|}{$\begin{array}{l}h l=0.25 R_{d}, \text { where } R_{d}-\text { the digging radius } \\
\text { at the hydraulic backhoe position level }\end{array}$} & \multirow{7}{*}{$\begin{array}{l}\text { Lower loading: } \\
\text { Liebherr R-984C; } \\
h l=3-4 \mathrm{~m} \\
\text { Liebherr R-994; } \\
h l=3-4 \mathrm{~m} \\
\text { Terex RH-90C; } \\
h l=3.5 \mathrm{~m} \\
\text { Volvo EC-460B; } \\
h l=3 \mathrm{~m} \\
\text { Komatsu PC-5500; } \\
h l=4 \mathrm{~m} \\
\text { Volvo EC-460BL; } \\
h l=4 \mathrm{~m}\end{array}$} & \multirow{7}{*}{$\begin{array}{l}h l=4-5 \mathrm{~m} \\
\text { The number of } \\
\text { layers, calculated as } \\
H c l z / h l \text {, is } \\
\text { accepted as } 2,3 \text { and } \\
4 . \\
\text { It is allowed: } 2 \text { or } \\
3 \text { layers of the full } \\
\text { height and one of } \\
\text { half-height; division } \\
\text { into equal layers } \\
\text { under condition of } \\
h l \text { less than } 4-5 \mathrm{~m}\end{array}$} \\
\hline \multicolumn{3}{|c|}{ The rational layer's height } & & \\
\hline \multirow{2}{*}{$\begin{array}{l}\text { Hydraulic } \\
\text { backhoe model }\end{array}$} & \multicolumn{2}{|c|}{$\begin{array}{l}\text { The layer's height for } \\
\text { truck loading, m }\end{array}$} & & \\
\hline & lower & upper & & \\
\hline Liebherr R-984C & $3.0-3.5$ & $2.0-2.5$ & & \\
\hline Liebherr R-994 & $4.0-4.5$ & $3.0-3.5$ & & \\
\hline Terex RH-200 & $4.5-5.0$ & $3.5-4.0$ & & \\
\hline
\end{tabular}

At present, there is no scientifically proved methodological approach to the design of layer-by-layer trenching and development of slopes by hydraulic backhoes in the coalbearing zone of the quarry fields.

To develop the basics of designing the technology for the development of coal-bearing zones by hydraulic backhoes, a number of problems must have been solved, including the following: analysis of the geological structure of trenches and excavator's stopes in the course of calendar planning; studying of structures of layered technological schemes of trenching and development of stopes; the order of planning of layer-by-layer development of trenches and benches. 
Possible variants of the construction of trenches and stopes, worked out in the process of development of mining operations along the front and to the depth, can be reflected on one layer (bench, horizon), if they are orthogonally projected onto one axis (so-called "calculated layer" - Fig. 1). The condition of this approach application is the safety of the dip angle of coal seams and their thickness to a depth of 2-3 horizons, as well as the height of the benches at the horizons [7-8].

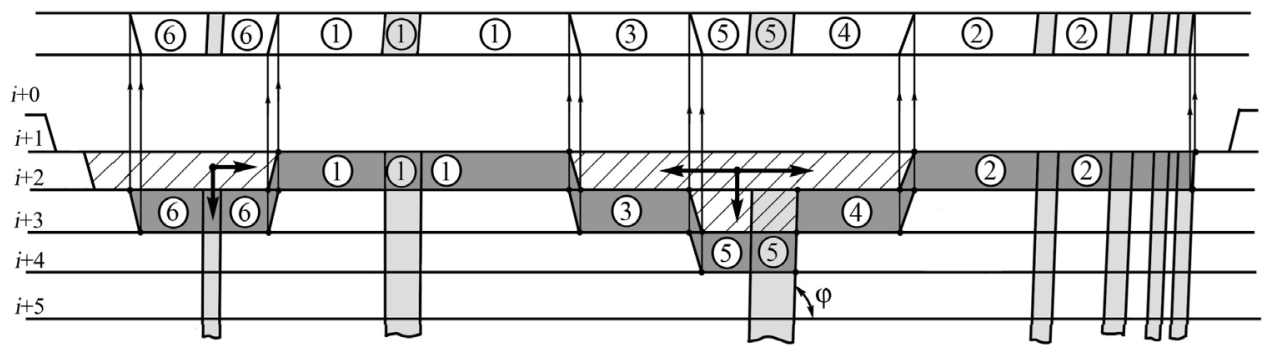

Fig. 1. Scheme of projecting trenches and stopes to the axis - "the calculated layer".

The arrows show the direction of movement and deepening of mining operations; $\varphi$ is the dip angle of coal seams.

The calculated layer has the following properties:

- the volume of the layer is equal to the sum of the volumes of trenches and stopes when deepening the mining operations to the height of the bench;

- in the layer there are clearly distinguished both rock and complex structured blocks of the coal mining operations;

- it is possible to calculate the volumes both of trenches and stopes, using the layer's parameters, as well as the volume of entire area of coal-bearing zone with the deepening of the mining operations to the height of the bench.

Thus, to study the options for the geological structure of trenches and stopes, the primary geological material (geological sections) can be used.

The analysis of geological material from developing and perspective for open pit mining deposits of Kuzbass (Kemerovo, Leninsky, Erunakov, Bachatsk, Prokopevsk-Kiselevsk, Kondomsky, Tom-Usinskoye) has shown the following.

When analyzing the structure of the benches, the seams' separation according to the dip angle was taken according to the systematization for Kuzbass open pits made by prof. V.F. Kolesnikov, according to which the range of dipping for inclined seams is $15-45^{\circ}$, for steep seams $-46-90^{\circ}[2]$.

Further, the regulating document of open pit mining in Russia is recommended to divide the seams by capacity into workable and non-workable [3]. For open pit mining, the minimum value of the thickness of the working seam is $2 \mathrm{~m}$.

In the Kuzbass open pits, when hydraulic backhoes are used for coal extraction, the minimum thickness of the seams is: "Kedrovsky" (Kemerovo seam is $2.34 \mathrm{~m}$ ); "Mokhovsky" (seam Gramoteinsky I - 1.4 m); "Bachatsky" (Lutuginski seam - 2.38 m); "Krasnobrodsky" (Lower Conductor seam IV - 1.94 m); "Kaltansky" (seam 9a - 2 m).

Based on these data, we accept the minimum thickness of the coal seams $-1.4 \mathrm{~m}$.

\section{Results and Discussion}

The stripping and coal extracting operations in the coal-bearing zone affects the mining technology from mutual position of adjacent layers that may be dispersed, connivent or mixed (converged) in the benches. Dispersed seams mean that they are processed by the 
technology of a single layer excavation; connivent seams mean excavation of two adjacent seams, between which it is impossible to make a cut trench (e.g., cut trenching required separating this seams) without damaging effects on the upper layer. Mixed dipping means separate groups of seams, which include both dispersed and adjacent layers.

Based on the assumptions above, the analysis of the geological structure of the benches on the quarry field horizons have showed the following.

For evaluation of cutting the stopes on the interbeds, their horizontal thickness $\mathrm{Mz}$ $(M z=M / \sin \varphi$, where $M$ is the normal thickness of a seam) is important, because the seams are cut in the stope regardless the dip angle but along the horizon considering the horizontal width of the interbed.

According to observations, the main frequency of the values of the parameter $M z$ is observed within the range of up to $100 \mathrm{~m}$, single observations was in the intervals 110-130 $\mathrm{m}, 160-180 \mathrm{~m}$ and $250-310 \mathrm{~m}$. These values are confined only to different segments with inclined coal seams of the Urop deposit in Leninsky district.

It should be noted that in $83 \%$ of observations the horizontal width of the interbed is within $60 \mathrm{~m}$. With this value of the width of the interbed, it can be worked out by the "technology of work with wide stopes": by one face during the shuttle move of hydraulic backhoe. Wider interbeds can be divided into two or three parts in width.

In special cases, with the horizontal width of the interbed equal to $130-310 \mathrm{~m}$, the use of rope shovels in coal-less zone cannot be excepted in order to intensify the overburden removal, which will make it possible to work out the benches inthe full height.

The total thickness of the coal-bearing zone $(M c b z)$ makes it possible to roughly determine the number of cutting stopes taking into account their distribution along the 2-3 benches. To do this, we constructed the distribution of $M c b z$ in width (Fig. 2-b).

The distribution of the horizontal thickness of the coal-bearing zone is practically uniform in the range from 100 to $800 \mathrm{~m}$. The values of $M c b z$ above $800 \mathrm{~m}$ is also applied to the sections of the Uropsky deposit.

Considering the open pit mining operations carrying-out, the number of cutting stopes including trenches shall be from 2 to $12-16$.

The mutual position of the coal seams on the horizons is characterized by two species.

1. The distributed bedding of lay seams ers (deposits Uropskoe, Teshskoe, Karakanskoe, etc.).

Their development involves the use of technology, characterized by the extraction of a single seam with the cut trenching from the side of the roof.

2. The distributed bedding of strata of closely located seams. This type of occurrence of seams has a predominant distribution (Karachiak and Korchakolskoye deposits, Novobachatsky site, Vinogradovsky and others).

A two-pronged approach is proposed for selecting a technology for developing coal seams with such bedding.

- the dispersed coal seams are developed using single seam technology.

- the choice of the technology for the development of groups of closely located seams should be made after checking the occurrence of the proximity of each two adjacent seams. Since the boundaries of the proximity of two adjacent seams are less than 5-7 $\mathrm{m}$, in the analyzed group there may be both convergent and dispersed seams, as shown in Fig. 2.

On the basis of this analysis, a decision on the technology of cutting stopes and trenching can be made.

Therefore, the main types of technological schemes structures are associated with groups of closely located seams.

It should also be noted that the structure of trenches and stopes (the number of seams in them) cutting in calendar planning is of a random nature, reflecting the random nature of the frequency and duration of formation processes in the Carboniferous period. 
The thickness of interbeds, respectively, also follows the random distribution pattern.

Nevertheless, the structure of trenches and stopes can be systematized according to the number of seams and their dip angle.

Inclined seam $\mathrm{s}\left(15-45^{\circ}\right)$

Steep seams $\left(46-90^{\circ}\right)$

(ispersion of the observation:

Fig. 2. Parameters of groups of seams occurrence.

Thus, the analysis of the geological structure of the coal-bearing zones, taking into account the equipment used in the coal-less zone, allows us to conclude that the height of the benches in the coal-bearing zone corresponds to the height of the benches in the coalless zone, and the geological structure of trenches and stopes being cut during calendar planning has a random character and is determined by the mutual position of the seams along the width of the coal-bearing zone (dispersed, connivent, or the structured as individual groups of closely spaced seams). The closeness of the seams is determined by the criterion of "proximity" - the minimum distance along the normal between two adjacent seams, with a maximum value of 5-7 $\mathrm{m}$.

The distribution of the horizontal thickness of the stopes made it possible, taking into account the application of wide stopes (40-60 m and more), to systematize the types of trench structure and stopes to the height of the bench $(H)$, including one, two, three and four layers seams. When cutting the stopes, it is taken into account that when working the wings of synclinal and anticline folds, the front of the work can move both in the direction of the seam's roof (we consider the occurrence of the seam as consonant) and in the direction of the bed (inconsonant occurrence). 


\section{Conclusion}

The foregoing allows us to draw the following conclusions.

The variability of the geological structure of trenches and stopes cut during calendar planning can be studied using horizontal geological sections equal to the height of the bench in the coal-less zone.

The mutual position of the seams on the horizons is characterized by two types: a) dispersed bedding; b) the dispersed bedding of seams and groups of closely located seams, which include as closely spaced seams (the normal interbed thickness between them is 5-7 $\mathrm{m})$, and dispersed.

The distribution of the horizontal thickness of the coal-bearing zone, which determines the number of the stopes, is almost uniform for the range from 100 to $800 \mathrm{~m}$. In this range, when wide stopes are used (40-60 m), the number of cut stopes is from 2 to 16 .

The distribution of the horizontal width of the interbed is linearly decreasing in the range from 10 to $100 \mathrm{~m}$, with $83 \%$ of observations are made within $60 \mathrm{~m}$. Then the majority of interbeds can be worked-out by wide stopes.

\section{References}

1. M. Tyulenev, O. Litvin, M. Cehlár, S. Zhironkin, M. Gasanov, Acta Montanistica Slovaca, 22:3, 296-302 (2017)

2. M. A. Tyulenev, S. A. Zhironkin, O. I. Litvin, E. A. Tyuleneva, O. V. Zhironkina, S. O. Markov, Geotechnical and Geological Engineering, 35:5, 2065-2077 (2017)

3. M. Tyulenev, O. Litvin, M. Cehlár, S. Zhironkin, M. Gasanov, Acta Montanistica Slovaca, 22:3, 296-302 (2017)

4. N. Demirel, S. Frimpong, International Journal of Mining, Reclamation and Environment, 23:1, 4-20 (2009)

5. N. Demirel, O. Gölbası, Minerals, 6:2, 51 (2016)

6. V. Gogolin, Y. Lesin, A. Djagileva, E3S Web of Conferences, 15, 01001 (2017)

7. V.A. Gogolin, Yu.A. Ryzhkov, Soviet Mining Science, 17(2), 156-159 (1981)

8. V.A. Gogolin, Yu.A. Ryzhkov, Soviet Mining Science, 13(1), 17-20 (1977)

9. S. Markov, M. Tyulenev, O. Litvin, E. Tyuleneva, E3S Web of Conferences, 15, 01011 (2017) 